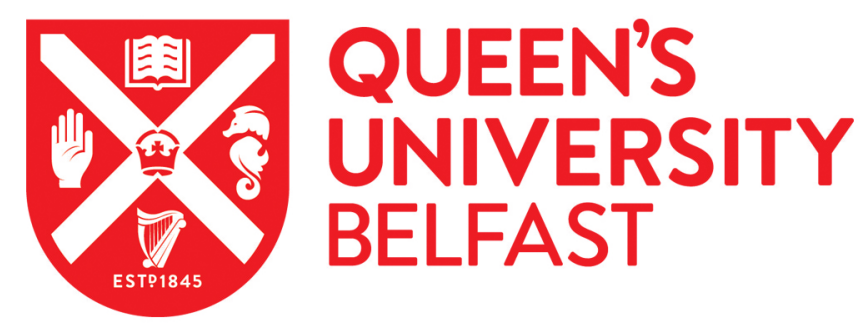

\title{
A Place Apart? The Interventions of John P. Mackintosh and Bernard Crick on Northern Ireland
}

Walker, G. (2017). A Place Apart? The Interventions of John P. Mackintosh and Bernard Crick on Northern Ireland. Contemporary British History, 1-18. https://doi.org/10.1080/13619462.2017.1401471

\author{
Published in: \\ Contemporary British History
}

Document Version:

Peer reviewed version

Queen's University Belfast - Research Portal:

Link to publication record in Queen's University Belfast Research Portal

Publisher rights

( 2017 Taylor and Francis. This work is made available online in accordance with the publisher's policies. Please refer to any applicable terms of use of the publisher.

\section{General rights}

Copyright for the publications made accessible via the Queen's University Belfast Research Portal is retained by the author(s) and / or other copyright owners and it is a condition of accessing these publications that users recognise and abide by the legal requirements associated with these rights.

Take down policy

The Research Portal is Queen's institutional repository that provides access to Queen's research output. Every effort has been made to ensure that content in the Research Portal does not infringe any person's rights, or applicable UK laws. If you discover content in the Research Portal that you believe breaches copyright or violates any law, please contact openaccess@qub.ac.uk. 


\title{
A Place Apart? The Interventions of John P. Mackintosh and Bernard Crick on Northern Ireland
}

\begin{abstract}
This article considers the significance of the scholarly and practical engagement with the Northern Ireland problem on the part of the Scottish politician and academic John P. Mackintosh, and the academic and controversialist Bernard Crick. It is argued that they were among the few scholars and public figures outside of Northern Ireland for whom the crisis represented an opportunity to explore more searchingly issues with broader significance for the UK as a whole, particularly devolution, and for relations within and between the islands of Britain and Ireland. For both men Northern Ireland brought into sharp focus questions of sovereignty and identity, and of constitutional reform in the UK.
\end{abstract}

Key Words: Northern Ireland conflict; constitutional reform; devolution; unionism; nationalism.

Between 1975 and 1978 the distinguished journal Political Quarterly was co-edited by Bernard Crick and John P. Mackintosh. ${ }^{i}$ The two men had been friends since Crick, embarking on what was to be a sterling academic career, favourably reviewed Mackintosh's classic study The British Cabinet when it was published in 1962. ${ }^{\text {ii }}$

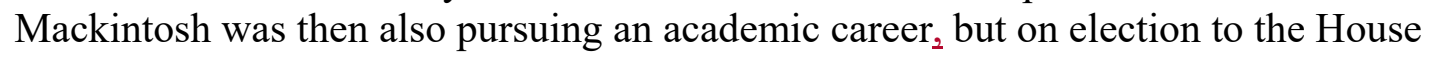
of Commons as Labour MP for Berwick and East Lothian in 1966 he in effect proceeded to combine the roles of politician and scholar for the rest of his life; he died at the age of 49 in 1978. After his death Crick did much to keep Mackintosh's memory alive and to highlight the value of his legacy as a political figure and thinker. Crick helped organise a special tribute in the House of Commons, and he established an annual memorial lecture. ${ }^{\text {iii }}$

The friendship was based on mutual political interests, and indeed passions. Both were maverick personalities who provoked strong feelings, both positive and negative, among colleagues. Both cared deeply about matters of democracy and government, and both valued the study and the teaching of politics as essential to the exercise of meaningful citizenship. They were both public intellectuals though decidedly not elitist in attitude. If Crick never ventured into politics as a career, he nonetheless sought engagement with 'the intrinsically messy, real world politics ${ }^{\text {iv; }}$; and Mackintosh never wavered from the belief that high quality scholarship should inform political practice.

This article considers the relationship of both Crick and Mackintosh to the question of the Northern Ireland troubles. Both became deeply interested in the political difficulties involved in ending the violence in the Province; the period from 1971 until 1976 was the most tragic in terms of loss of life. The nature of both men's interest in, and engagement with, Northern Ireland will be explored for the 1970s, and Crick's personal contributions in subsequent decades to finding a solution will be evaluated. It will be contended that Crick and Mackintosh's thinking on Northern Ireland was related to broader themes around governance, devolution and the UK constitution, and the nature of the inter-relationships that distinguish the British Isles. 
From the time of his election to Westminster in 1966, Mackintosh was a dogged advocate of devolution and the de-centralisation of power throughout the UK. In 1968 he published a book that fed into the debate then current around local government reform and regionalism, and contributed to the ferment of political speculation triggered by the upsurge of Scottish and Welsh Nationalism. ${ }^{\mathrm{V}}$ For Mackintosh, the grievance politics of the Nationalist parties required the Labour government to be bold in its championing of constitutional reform and modernisation.

Mackintosh viewed devolution as essentially a form of local government that provided better standards of democracy: it brought government closer to people's lives and fostered greater participation and involvement. He had immersed himself in the academic study of governance and approached the subject, as he put it in an essay published in 1976, from the standpoint, not of Nationalism, but of a desire for 'a more democratic and vital form of local self-determination. ${ }^{\text {'vi }}$

There was thus a suggestion of the scholar in search of the text book example in Mackintosh's keen interest in the Northern Ireland experience of devolution between 1921 and 1972. This interest was evident as early as 1964 in an essay that challenged previous unfavourable evaluations of Stormont (the Northern Ireland Parliament). Mackintosh $_{2}$ by contrast ${ }_{2}$ argued that devolution had proved popular in Northern Ireland, that elected representatives and officials were more easily accessible, and that the needs of the Province were served effectively. He was cognisant of the extent to which Northern Ireland had chosen to remain 'step by step' with the rest of the UK, especially in welfare benefits and services and social and economic legislation; yet Mackintosh took the view that there were still significant differences in legislation and in providing for distinctive needs, and that adhering to 'step by step' in some areas was simply an option that was permitted in the more flexible context provided by devolution. ${ }^{\mathrm{vi}}$ In his 1968 book $_{2}$ Mackintosh used Northern Ireland to support his call for broader de-centralisation, and to refute the anti-devolution argument that it would lead inevitably to separation. Mackintosh's desire was for a new system of regional councils in England, and assemblies for Scotland and Wales, with powers similar to Stormont. He believed such reforms would avoid what he saw as the unnecessary rigidities of a formal federal system, and preclude any slide to separation. ${ }^{\text {viii }}$

It was Mackintosh's misfortune, from the point of view of the cogency of his devolution arguments, that Northern Ireland should descend into civil strife at just the point when some governmental and democratic re-structuring looked to be in the offing in Britain. ${ }^{\text {ix }}$ In August 1968 Mackintosh referred to opponents of change citing Northern Ireland as if it provided a 'telling riposte' to the reformers, and countered with the assertion that there was a great deal to be learnt from what had occurred in Northern Ireland since 1921. He instanced the way that notions of clear distinctions between 'internal' and 'imperial' functions of government, that underlay the 1920 Government of Ireland Act, were tenuous even then and could not be held to in the much-changed circumstances of the second half of the twentieth century $: \dot{\overline{9}}$ Ffurthermore, he insisted that the Northern Ireland example showed that if a generous measure of devolution was first extended, then there was always the likelihood that, in line with the wishes of the local electorate, certain powers and responsibilities could be returned to the centre or agreement reached on what might be best run on a 
common basis, while the advantages of local variations would be retained. Using Northern Ireland as the benchmark, Mackintosh urged that Scotland and Wales be given substantial devolved powers with the expectation that there would be adjustments and modifications in the future; this, he averred, was preferable to insisting upon 'an outdated and irritating centralisation'. $x$

However, if there was a tendency on the part of the defenders of the constitutional status quo to disparage the Northern Ireland experiment as it had worked up until 1968 , there was an even more pronounced readiness to indict devolution as a system for the chaos in which the Province was enveloped from late 1968. Devolution then became caught up in the 'troubles' narrative. Nevertheless, Mackintosh did not take the convenient route of leaving Northern Ireland out of his arguments $\div$; any suggestion that political violence resulted from devolution 'per se', and he continued to stress its relevance to the broader UK constitutional deliberations, and reminded everyone of the centrality of Ireland as whole to the history of devolution in the UK. Mackintosh made reference to Northern Ireland in his personal submission to the Royal Commission on the Constitution in $1970,{ }^{x i}$ a year after the Commission was set up by the Labour government as a response to the growth of Nationalism, and increasing disquiet about centralised government. In 1973, as Westminster debated the Heath Conservative government's White Paper on the way forward for Northern Ireland following the suspension of Stormont in March 1972, Mackintosh, cognisant of the connections between the Northern Ireland problem and the forthcoming Royal Commission Report, ${ }^{\text {xii }}$ declared the former Northern Ireland arrangement to have been 'an administrative success'. xiii

Mackintosh developed good parliamentary relationships with fellow MPs Robin Chichester-Clark (brother of the Northern Ireland Premier between 1969 and 1971) ${ }^{\text {xiv }}$, and Gerry Fitt who became leader, at its inception in 1970, -of the Nationalist Social Democratic and Labour Party (SDLP) at its inception in 1970. He claimed to be in close touch with Northern Ireland Secretary of State William Whitelaw during 19723 , and he visited Northern Ireland himself to gain first-hand impressions of the situation. Moreover, he was in correspondence about the Northern Ireland problem from its outbreak with fellow academic, Dr. Geoffrey Hand ${ }_{2}$ who was based in Dublin. ${ }^{\mathrm{xv}}$

Hand wrote to Mackintosh following the Civil Rights march in Derry on 5 October 1968 that culminated in confrontation with the Royal Ulster Constabulary (RUC). Hand was a liberal Protestant observer, severely critical of the Northern Ireland regime; he informed Mackintosh that Prime Minister Terence O'Neill was 'about as effective a Liberal force as Dubceck.' Mackintosh replied that it was unclear whether the British government had 'residual rights' to intervene and enforce change to the electoral system and housing allocation arrangements, but conceded that people in Britain were not seriously prepared for such a move. It was Mackintosh's hope that Britain would be able to effect change without having to 'break down the structure of the 1920 Act.' It would hardly have helped Mackintosh's contemporaneous advocacy of devolution in Britain, for the Northern Ireland example to have been wound up at this juncture. As he also remarked to Hand, the purpose of his devolution book was 'to try and discourage Scottish Nationalism from going through to the Eire type solution and to adopt what I regard as a more satisfactory Home Rule solution. 'xvi

The inter-communal violence of August 1969 led Hand to call for the disbandment of the 'B' Specials (an auxiliary part-time police force despised by the Catholic minority) and the re-drawing of the border to hand over territory that had been identified as suitable for transfer by the Boundary Commission back in 1925 . $^{\text {vii }}$ 
Mackintosh's view at this juncture was that border re-adjustments were beside the point,_which was to break the power of the Unionist Party, 'get fair treatment inside Ulster', and 'forget the old arguments about partition'. On the first point, Mackintosh went as far as to consider the suspension of Stormont for an interim period during which there would be a chance for a 'new Centre Party' to emerge and hopefully sweep a subsequent election. A month later Mackintosh still doubted whether the Unionist Party could ever provide satisfactory government for the whole community, but expressed the wish that it would be 'phased out' rather than 'pushed out'. ${ }^{\text {xviii }}$

By 1972 the Irish Republican Army (PIRA) campaign had pushed Mackintosh towards what were for him rather illiberal standpoints. Writing to Hand in the wake of 'Bloody Sunday', he observed that IRA (both 'Provisional' and 'Official') ${ }_{2}^{\text {xix }}$ atrocities had complicated reactions in Britain, and that he himself felt 'hostility' to the Civil Rights movement for 'flouting' the ban on marches, something he supported strongly. He went on to endorse the 'solution' of re-partition (without acknowledging Hand's previous advocacy of it) and 'a wholesale movement of the Catholic population of the north-east to the Border areas and then the cession of these Border areas to the South.' He claimed that such a plan was under active consideration in the Cabinet. ${ }^{\mathrm{xx}}$ Hand later referred to Mackintosh calling his re-partition plan the 'Sudetenland policy' and expressed the hope that Mackintosh was not in any way advocating the expulsion of members of the minority community if they were unwilling to leave. ${ }^{\mathrm{xxi}}$ Mackintosh's response is not recorded.

Mackintosh claimed that he saw Whitelaw 'fairly often' about Northern Ireland, and he certainly supported the approach the Secretary of State took in his White Paper of March 1973. His comments on it in the House of Commons indicate that he had quickly rowed back from his flirtation with the idea of population movements. However, he confessed his anxiety that if the White Paper proposals did not work there was no other solution to which the government could turn: 'My worry is that the White Paper will be the end of the road. It is the logical end point in terms of persuading the two communities to live together within the same geographical area. ${ }^{\text {'xxii }}$ In the wake of the Sunningdale Agreement at the end of 1973, Mackintosh was full of praise for Whitelaw's achievement but he was also mindful of Unionist leader Brian Faulkner's potential problems ${ }^{\text {xxiii }}$, and he correctly predicted a short time later the political difficulties that the general election outcome of February 1974 would cause for progress in Northern Ireland. ${ }^{\text {xxiv }}$

Mackintosh himself lost his seat in this election ${ }_{2}$ although he won it back in the October poll that saw Labour obtain a slim majority. He was thus at Westminster during the febrile aftermath of the IRA Birmingham pub bombings in November. In a letter to Hand, Mackintosh declared that he was 'prepared to vote for the death penalty for this kind of calculated horror by terrorists.' In despair, he added that he was again 'toying with the idea of movement of population and redrawing the boundary. ${ }^{\mathrm{xxv}}$ The following month he informed Hand that he had only been persuaded against voting for the death penalty by the speeches in the House of Roy Jenkins (Home Secretary), and Brian Walden, an ally on the right wing of the Labour Party. ${ }^{\mathrm{xxvi}}$

This episode and the earlier ones on which Mackintosh's correspondence sheds light, show that as a politician he was just as influenced by popular opinion and pressure as most, and just as inclined to think 'on the hoof' about possible measures to deal with a situation that threatened to spiral out of control and, certainly in late 1974, convulse the social fabric of the British mainland. However, Mackintosh was simultaneously a scholar, and impulsive responses were usually supplanted by deeper 
reflection. Moreover, he never ceased to keep in mind the larger context of the impact of the Northern Ireland question on UK society and political culture and on the prospects of constitutional reform and democratic renewal. It is clear that the Northern Ireland problem caused Mackintosh, far more than most British politicians of whatever party, genuine anguish and concern: he was acutely aware of how much was at stake, and he was never content to regard Northern Ireland as 'a place apart'.

In 1975, indeed, he returned in a scholarly sense to the Province with an in-depth analysis of how devolution had worked in Northern Ireland and how comparisons could be drawn with the federal example of Canada. ${ }^{\text {xvii }}$ This academic paper in fact represented the development of his argument in 1968 that the Northern Ireland precedent might be viewed as a positive one for pro-devolutionists if viewed in a certain light. Mackintosh contended that Northern Ireland, in a similar manner to certain Canadian Provinces, had been an example of 'co-operative federalism' whereby the possession of certain fiscal capacities and significant legislative powers were balanced by the maintenance of a coherent and consistent economic policy and common standards of welfare and services across the whole polity. At this point in the UK's devolution debate, Mackintosh was concerned about the need for a devolved Scotland to prove that it could benefit by doing certain things differently notwithstanding the economic constraints and the desire, as had been the case in Northern Ireland, for the retention of a substantial swathe of common UK standards and entitlements. In this connection, Northern Ireland was Mackintosh's research laboratory out of which he clarified his thinking on UK devolution more broadly, and on Scottish prospects in particular. Northern Ireland, he believed, had evolved from its 'federalist' design and had, within limits, functioned to demonstrate that the UK could accommodate diverse governing arrangements.

In bringing Northern Ireland to the wider UK debate, Mackintosh illustrated its value to the 'Union State' school of thought about UK governance. ${ }^{\text {xxviii }}$ The Northern Ireland example underscored the reality of the UK's essential diversity, whether political, cultural, or institutional. It served as a reminder that devolution and constitutional change had an important history and an experience from which lessons could be learnt for future devolved government schemes. Mackintosh often reflected on the circumstances of the South of Ireland's departure from the $\mathrm{UK}_{2}$ and took from this a warning that Scotland could go the same way if devolution was not granted, and if respect for, and accommodation of, national distinctiveness was not freely given. ${ }^{\text {xxix }}$ Unlike those who clung to the notion of a unitary state that any measure of devolution would only dismember, Mackintosh did not view Northern Ireland as a constitutional misfit. Where those who subscribed to the 'Unitary State' school of thought routinely excluded Northern Ireland from their frame of reference and favoured exceptional arrangements being made for $\mathrm{it}^{\mathrm{xxx}}$, Mackintosh considered it relevant to his conception of the UK as quasi-federal, both in terms of its history and future potential.

Bernard Crick (1929-2008), like Mackintosh, was a scholarly authority on the politics and governance of the UK and deeply concerned with the prospects of constitutional reform. Like Mackintosh, he valued the application of political theory to practical solutions, and had no time for abstract academic debate that failed to connect with and inform actual political developments. ${ }^{\text {xxi }}$ Crick worked tirelessly throughout his 
academic career and beyond to promote politics as a subject to be taught in schools, as part of a broader set of citizenship studies. ${ }^{\text {xxxii }}$ In common with Mackintosh ${ }_{2}$ Crick was also among the few scholars for whom the Northern Ireland crisis represented an opportunity to explore more searchingly issues with broader significance for the whole UK: the nature and potential of devolved government; questions of representation and minority rights; the accommodation of different identities and aspirations. Indeed, Crick and Mackintosh considered it a duty to grapple with the political dilemmas and constitutional conundrums thrown up by Northern Ireland, and not regard the Province's particularities as simply out of kilter with contemporary Britain and thus able to be boxed up and dealt with separately. Crick and Mackintosh were both wary of approaches to Northern Ireland that laid too much stress on its characteristics as a 'special case': such an approach often led to the simplistic belief that the Northern Ireland problem could be reduced to that of an ancient tribal and religious feud. As Aughey and Gormley-Heenan have observed, Crick engaged with the problems of Northern Ireland in accordance with his beliefs about the role academics should play in public life. ${ }^{\text {xxxii }}$

Crick began visiting Northern Ireland from the outbreak of the 'troubles' in 1969 to promote the work of the Hansard Society and his ideas on political education in schools. ${ }^{\text {xxxiv }}$ Then, in the summer of 1975 , he was approached to advise the United Ulster Unionist Council (UUUC) group in the recently formed Constitutional Convention. ${ }^{\mathrm{xxv}}$ The Convention was set up by the British Labour government ostensibly to give the local Northern Ireland politicians a forum through which they might endeavour to make political progress, with the British government effectively on the side-lines. ${ }^{\text {xxxvi }}$ Nevertheless, the government's wish to see as much crosscommunity participation in a future government and Unionist-Nationalist cooperation as practically possible was clearly signalled. ${ }^{\text {xxxvii }}$

The approach to Crick came initially from David Trimble, then a representative of the Vanguard Unionist Party led by William Craig. Vanguard formed, along with the 'Official Unionists' led by Harry West and the 'Democratic Unionist Party' led by Ian Paisley, the UUUC coalition that held 47 of the Convention's 78 seats. Trimble, increasingly relied upon by Craig at this juncture for political thinking and forensic attention to detail, ${ }^{\mathrm{xxxviii}}$ was convenor of the UUUC sub-committee on minority participation. Writing to Crick, Trimble stated that they were hopeful of establishing a committee system in a new Northern Ireland Assembly that would give an opposition both 'status and effective power'. He said he had consulted relevant works of Crick such as his Reform of Parliament. ${ }^{\text {xxix }}$

On 30 September 1975 Trimble publicised in the Convention the UUUC's thinking on the subject of a Committee system stressing, among many other points, that it was envisaged that the Opposition would hold at least half of the chairmanships. Trimble referred to Crick's role in the development of these plans and quoted Crick's favourable response to the proposals: 'I think it goes as far as a parliamentary system can go in this direction, would be seen as an imaginative and genuine initiative and shows sensitivity, within your ranks, not merely on behalf of an agreement with the minority parties, to general fears of too much executive power. ${ }^{\mathrm{xl}}$

In his scholarly appraisals of UK politics Crick had long been concerned with stemming what he saw, along with reform-minded MPs like his friend and fellow editor of Political Quarterly Mackintosh, as the drift towards centralised executive power and the erosion of the proper practice of representative government. In advising the UUUC, Crick was alive to the possibility of, in his view, what he viewed as more progressive governing arrangements being devised in a part of the UK that 
would form an example to be emulated more broadly. Northern Ireland was not a sideshow: it could instead point the way if politics was enabled to prevail and imaginative solutions allowed a chance to work. It is clear that Crick relished the chance provided in Northern Ireland in 1975 to involve himself in practical politics, even if his previous friendships with key figures in the SDLP had not made him a predictable choice to work with on the part of Unionists. However, as Crick makes clear in his own record of this episode, Craig probably was drawn to Crick at least in part because of his SDLP connections and the possibility that he could be an effective go-between. ${ }^{\text {xli }}$ Equally, Crick came quickly to realise that Craig was sincere in his desire for accommodation with the SDLP, and that he had travelled far politically from the early days of Vanguard when he was widely viewed as the most hard-line of the various Unionist political leaders following the suspension of the Stormont Parliament in March 1972. ${ }^{\text {xlii }}$

By the time Trimble had made public Crick's endorsement of the UUUC's proposals on Parliamentary committees, the matter had been overtaken dramatically by the controversy over Craig's offer to form a 'voluntary coalition' with the SDLP on the lines of a national government in an emergency situation. With Unionist opinion in mind, Craig likened this to the emergency coalition formed in Britain during the Second World War and fronted by Churchill. In the wake of the fall of the short-lived power-sharing executive of January-May 1974, it was crucial for Craig to make a distinction between his idea of voluntary coalition and the loaded and tarnished term 'power-sharing' which was viewed by most in the majority Unionist community as an imposed set of arrangements designed to render Northern Ireland less British. Craig believed he could push forward on the basis of the UUUC and the SDLP's common desire for a substantial degree of devolution, including powers over security, but he was denounced by Paisley and forced to resign the leadership of the Vanguard Party in the Convention when the proposal was voted down in the UUUC; the sticking point was that of places in cabinet for the SDLP. ${ }^{\text {xliii }}$ The Vanguard Party duly split with Craig and those who remained loyal to him being expelled from the UUUC. These events took place in September 1975 in the context of a deteriorating security situation and the massacre of four Protestants at Tullyvallen Orange Hall on the first day of the month. As was repeatedly the case in this phase of Northern Ireland's history, tragedy hardened opinions and accorded political initiatives too little room to develop.

Nevertheless, this initiative may have come closer to success than is often thought. That was certainly Crick's view, expressed in the Political Quarterly in late 1976 and periodically in his writings on Northern Ireland subsequently. ${ }^{\text {xliv }}$ In his personal papers of the time he recorded his conviction that hopes of progress were not without good foundations, that there was 'a basis of trust' between Craig and the SDLP 'that could broaden', that the SDLP had gone far in allaying Unionist fears over Irish unity, and that both sides desired 'as high degree of devolution as possible' ${ }^{x l v}$ Furthermore, Crick's notes and correspondence in the weeks following the breaking of the news about Craig's initiative made clear that he believed that Paisley also accepted the idea, a matter made public by Crick in January 1976 and promptly denied by Paisley. ${ }^{\text {xlvi }}$ Crick claimed that at a meeting on 2 September attended by Craig, West, Paisley, Trimble and himself, discussion of the Committee proposals was premised on the likelihood of agreement between Craig and the SDLP. ${ }^{\text {xlvii }}$ In a letter in October to fellow academic, Richard Rose, Crick asserted that the leaders of the SDLP in the Convention had been discussing 'in considerable detail' the possibility of an emergency coalition with West and Paisley as well as with Craig for some ten days 
before Craig's motion on the matter was defeated in the UUUC caucus on 8 September. Crick maintained that the SDLP leadership triumvirate of Gerry Fitt, Paddy Devlin and John Hume had accepted in principle the formula of accepting seats in a coalition that would be announced as for the duration of the emergency. Crick referred to 'an incredible week' when he 'heard it from the great man myself, Paisley had said in private that he would go along with it.' ${ }^{\text {'viii }}$

Notwithstanding the setback of the UUUC vote on 8 September, Crick continued to believe that a breakthrough was possible. He urged more support from the British government and press and sought to impress upon such quarters the damaging consequences of the prevalent rumours of possible British withdrawal; he called on Merlyn Rees as Secretary of State to build up the self-esteem of Convention members and give them more specific direction. ${ }^{\text {xlix }}$ On 24 September he met with the Chairman of the Convention, Sir Robert Lowry, and expressed his concern over 'the lack of thinking' on the part of the Westminster parties on Northern Ireland. Significantly, he also reflected critically on what he saw as the SDLP's insistence that 'cabinet membership was the only locus of power', and advanced the view that they could have made ground on other UUUC proposals such as stronger committees and a more interventionist role for a Governor. ${ }^{1}$ Writing to Craig in early October, Crick referred to conversations he had had with Northern Ireland Office (NIO) personnel and predicted - as it turned out rightly - that the Convention would go into a second phase following its adjournment in November 1975. Crick relayed the Government's pessimism about Paisley's capacity to act as a spoiler; yet he declared himself hopeful that Craig could 'cut into West's men in Round 2' and win the political battle inside the UUUC. ${ }^{\text {li }}$

Crick's reading of the UUUC dynamic was also that of Craig's who was confident that Paisley could yet be isolated. It was widely believed that Enoch Powell's influence had been brought to bear on the Official Unionists in rejecting voluntary coalition ${ }^{\text {liii }}$, however, the party's leader Harry West was firmly opposed to Powell's integrationist position and resented the way he appeared to be influencing political developments from Westminster. ${ }^{\text {liii }}$ The UUUC report that accompanied what became the first phase of the Convention was received coolly by Rees on account of its majoritarian thrust, and Crick later denounced it as 'totally unrealistic and unacceptable' liv In meetings with Rees and NIO officials late in $1975_{2}$ Craig still appeared confident of striking a deal with the SDLP; he stated that the UUUC would soon have to face 'the facts of life' and claimed to have the support of Official Unionists 'in the constituencies'. lv

Developments in Northern Ireland at this juncture coincided with moves towards devolution for Scotland and Wales: the Labour government produced late in 1975 a White Paper, 'Our Changing Democracy', which foreshadowed draft legislation the following year. It was a moment of potential constitutional reform and governmental transformation for the UK that invited serious joined-up thinking about the purpose of devolution and the future relationships between the different parts of the polity as a whole. It was a prospect that appealed to politicians like Mackintosh and to scholars like himself and his co-editor Crick. In September 1975 Crick envisaged 'some federal devices' emerging from the deliberations on Scottish devolution that he felt could be helpful in relation to political progress in Northern Ireland: 'I say this because if agreement on a wider coalition supporting a new frame of government acceptable to the Secretary of State breaks down, I think it possible that from out of the Scottish conditions, minds may be widened, both in the SDLP and the British Labour Party about the possibility of constitutional guarantees to minorities other than 
sharing in the cabinet of an executive.' Crick at this point took the view that even a form of power-sharing in Parliament instead of in government, and limited or selective legislative devolution on what might be the Scottish model, could be explored. ${ }^{\text {lvi }}$ Like Mackintosh, Crick regarded devolution not as a fixed set of arrangements, but as something capable of being adapted and altered to fit the particular needs and wishes of the different parts of the UK. He did not seek a uniform system of devolution; rather, he envisaged variations in the extent of the legislative responsibilities devolved and a sharing of responsibilities between the region and the centre. Like Mackintosh, Crick at this juncture did not think it necessary or advisable to reconstruct the UK along formal federal lines, yet he welcomed developments that took the UK in a federal direction. ${ }^{\text {.vii }}$ His writings regularly drew attention to what he was fond of calling the 'quasi-federal' realities of the UK. ${ }^{\text {lviii }}$ Far from hiving off consideration of the Northern Ireland problem from broader questions of UK constitutional change, Crick detected possible benefits in linking it to deliberations around Scotland in particular; he was alive to the possibility that devolutionary change in one part of the UK could be a catalyst for changes elsewhere and, indeed, for the strengthening of parliamentary democracy and government. When the government's proposals for Scotland materialised in 1976 he mused in the 'Political Quarterly' about how they might also suit Northern Ireland. ${ }^{\text {lix }}$

However, it was precisely the criss-crossing of the Northern Ireland challenge with the difficulties surrounding UK devolution that vexed Merlyn Rees. From his vantage point $_{2}$ developments around Scotland and Wales could bring unwelcome pressure for similar measures to be extended to Northern Ireland. ${ }^{\mathrm{x}}$ In February 1976 when the idea of putting a possible agreement on Northern Ireland to the electorate in a referendum was floated, Rees warned that this would have problematic implications for the Scottish and Welsh cases. ${ }^{\text {lxi }}$ Rees may also have had in mind the extent to which there was a considerable body of opinion in the UUUC that viewed developments around Scotland and Wales as providing the chance to pushing for an old style Stormont arrangement. Moreover, Powell frankly admitted to both Rees and Prime Minister Harold Wilson in October 1975 that his desire to 'play the NI question long' - what Craig called Powell's desire to put devolution 'on the long finger' - was helped by ensuring that the Northern Ireland case did not move ahead of that of Scotland. ${ }^{\text {lxii }}$ Rees could see only political trouble in relating the Northern Ireland question to broader UK issues, and his Secretaryship was characterised by a pronounced caution and vagueness over the political direction he favoured for the Province. He certainly was not inclined to encourage innovative thinking of the kind Crick felt was essential for progress.

Crick also despaired of the persistence of a 'Diceyan' strain of thought in British public life about the supposed sovereignty of the Westminster Parliament and the need to ensure its continuance; Powell was the most lucid defender of this tradition. Crick and Craig enjoyed a meeting of minds over this key area of constitutional debate. For Craig, it was still a sore point that Westminster had snatched back in 1972 the devolved powers Northern Ireland had possessed since 1921. ${ }^{\text {Ixii }}$ His argument was that Stormont had been the ultimate source of political authority; as Garry Watson has observed, this was a view grounded in a quasi-federalist interpretation of Northern Ireland's constitution. ${ }^{\text {lxiv }}$ Craig was able to make references in support of his interpretation to constitutional legal experts such as F. H. Newark, ${ }^{\mathrm{lxv}}$ and to maintain that the Ireland Act of 1949, which gave the final say on Northern Ireland's constitutional status to the Stormont Parliament, should not have been overridden. It was indeed the view of some in British government circles before the prorogation of 
Stormont that such an act would be constitutionally questionable, ${ }^{1 \mathrm{xvi}}$ while senior Stormont official Ken Bloomfield wrote in a memo in 1974 that the Northern Ireland government had not been a subordinate authority to the UK government in relation to those areas of responsibility that had been transferred. ${ }^{\text {lxvii }}$

Crick's writings on UK politics from the time of his involvement with the Northern Ireland problem are much preoccupied with the theme of parliamentary sovereignty ${ }_{2}$ and with Crick's perception of it as an obstacle to progressive change. In 1977 he observed that 'Parliamentary sovereignty and pluralism do, indeed, mix badly', lxviii while in 1979 he wrote that 'the prejudices of unitary sovereignty have grown dangerous as well as absurd. 'xix Crick was drawn to the Northern Ireland political conundrum, in addition to reasons already noted, on account of the way that Northern Ireland's history of devolution posed questions about the exercise of sovereignty, and the significance of developments such as the 1973 Northern Ireland

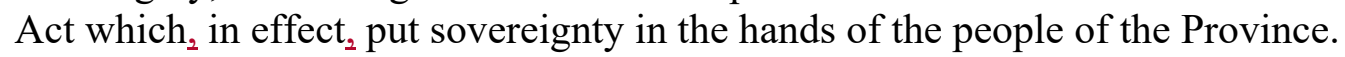
Northern Ireland's constitutional and political status was anomalous in the context of the sovereignty of parliament doctrine. ${ }^{\mathrm{lxx}}$ Consideration of the Northern Ireland question helped, in a manner of speaking, to take the sovereignty of parliament doctrine down from its pedestal and to de-mythologise it; it encouraged the notion that it need not stand in the way of progressive change which, for Crick, meant a 'de facto' if not 'de jure' federal framework for the whole UK. ${ }^{\text {lxxi }}$ By the mid - 1970s, moreover, the notion of absolute Westminster sovereignty had already been undermined by the UK's entry into the EEC, its membership endorsed in a referendum in 1975. ${ }^{\text {lxxii }}$ For Crick, a greater engagement with Northern Ireland by politicians $s_{2}$ and indeed academics and opinion-formers ${ }_{2}$ would help to change what he later referred to as 'presuppositions about parliamentary sovereignty and the nature of power'. 'xxiii

In a Westminster debate on the Constitutional Convention in January 1976, in which Gerry Fitt referred to Crick's claims about Paisley having accepted the voluntary coalition idea, ${ }^{\text {lxxiv }}$ Craig stated that they could not talk about the integrity of the UK if they at the same time insisted that 'the integrity of the United Kingdom depends on the sovereignty of this Parliament.' The sovereignty of Westminster, he continued, was 'in many respects a legal fiction'; its authority, he averred, 'rests with the people'. 'As we apply our minds', Craig argued, 'to the future pattern of government for the United Kingdom we should have before us at all times the necessity to obtain a mandate from all the peoples of the United Kingdom to maintain this unity.' He added that the people of Northern Ireland were asking for devolution in a form with characteristics more in keeping with a "federal system of government" than with the system of devolution then envisaged for Scotland and Wales. ${ }^{1 \times x v}$ This was the language of popular sovereignty that was to define the Scottish Constitutional Convention of the late 1980s and early 90s in which Crick was to be so deeply involved. ${ }^{\text {xxvi }}$ Later in 1976, in a debate on the Scotland and Wales Bill, Craig intervened to make the point that 'it is wrong to assume that the unity [of the UK] need be threatened by a sharing of power in altered measures or devolution or in a federal system.' ${ }^{\text {xxvii }}$ His speech indeed $_{2}$ was praised in the House by Mackintosh. ${ }^{\text {lxxviii }}$

The Convention was finally wrapped up by Rees in March 1976, following calls made in vain by Craig and his allies to put the matter of voluntary coalition to a referendum. ${ }^{\text {lxxix }}$ Talks between the UUP and the SDLP did continue beyond the Convention and occasionally promised a breakthrough, but Paisley's opposition was again a crucial factor in their ultimate failure by the end of the summer. ${ }^{1 \times x x}$ Craig, writing to Crick at the end of March 1976, confessed to feeling 'humiliated and 
degraded' by the setback he had suffered ${ }_{2}$ although he believed that another opportunity could yet present itself. ${ }^{\text {lxxi }}$

It was not to be. The UUUC broke up acrimoniously in May 1977, by which time the Unionists at Westminster, led by Molyneaux and Powell, had taken advantage of the parlous parliamentary situation that the Labour government found itself in to press an integrationist agenda. A loose agreement with the Callaghan government resulted in a measure to increase the number of Northern Ireland MPs at Westminster, ${ }^{1 \times x x i i}$ an accomplishment that Powell hoped would convince Ulster Unionists in general to turn from the pursuit of devolution and concentrate on playing a full part in the 'Mother of Parliaments'. 'xxxiii The new Northern Ireland Secretary of State, Roy Mason, quickly came to a sceptical view of the value of political initiatives and instead focused on strengthening Direct Rule, thus giving Molyneaux and Powell more encouragement. Notwithstanding the Callaghan government's decision to proceed with devolution legislation for Scotland and Wales after an initial parliamentary setback in February 1977, the opportunities for Craig to re-launch his voluntary coalition idea, controvert the Powellite integrationist thrust, and insert Ulster into a 'federalising turn' in UK constitutional history, could not be fashioned. ${ }^{\text {lxxxiv }}$ Indeed, Craig's valedictory political moment came at the general election of May 1979 when, now back in the UUP fold, he was narrowly defeated for the seat of East Belfast by the DUP's master strategist and future leader, and future First Minister of Northern Ireland, Peter Robinson.

If Craig's career was ruthlessly terminated, Crick's if anything blossomed as he proceeded to produce a series of stimulating writings around the theme of the need for constitutional and democratic reform in general, and an imaginative and workable compromise to end conflict in Northern Ireland in particular. Arguably, Crick derived much insight into the realm of what could be possible in Northern Ireland from his practical involvement with Craig, however unsuccessful the episode at the time had proved. In the 1980s, Crick was instrumental, along with other academic figures such as Kevin Boyle and Tom Hadden, in leading discussion towards more flexible arrangements for Northern Ireland and away from fixed concepts of sovereignty, identity and allegiance. . $^{\mathrm{xxx}}$

Crick was consistent from the early 1980s in his advocacy of arrangements for Northern Ireland that accommodated the reality that it faced in two directions: both to Britain and to the rest of Ireland. He recognised the need for both North-South and East-West dimensions to any overall scheme that would have to have an agreed form of devolution for Northern Ireland at its centre. The potential interactions between the Scottish and Northern Irish constitutional questions in the late 80s and early 90s stimulated him: he was alive to the possibilities of one or the other or both of them triggering broader, radical reform of the entire UK system as he had been in the 1970s. ${ }^{\text {lxxxvi }}$ Seminal essays such as 'The Sovereignty of Parliament and the Irish Question' prospected intellectual territory that other scholars, in the 'post-nationalist' context of the time, would plough in the 1990s with profound ramifications for the Northern Ireland peace process. ${ }^{\text {lxxxvii }}$ Indeed, the open-ended and pluralist nature of the Good Friday Agreement of 1998 with its stress on equality of esteem for different identities and space for the pursuit of different futures, bore the stamp of the Crick prescription contained in writings that spanned the period of both failed and transformative initiatives, important talks both secret and public, and continuing violence and tragedy from the early 1980s through to the late 1990s. 1xxxviii

Crick tried doggedly to show that holding more than one identity should be regarded positively, and not as problematic; he drew on his old colleague John 
Mackintosh's discussions of the dual identity held by most Scots and sought to extend the principle and the analysis across the UK and indeed 'these islands' of Britain and Ireland. ${ }^{\text {lxxix }}$ In this he was also somewhat ahead of the game in anticipating the way that more political attention has come to be paid to the matter of 'interrelations' across the archipelago and to the complexities of identity arising out of factors such as cultural interaction, migration, and new technology. Crick was embarking on a major study of the different relationships within the British Isles when he died in 2008. ${ }^{\mathrm{xc}}$

Mackintosh and Crick were examples of a rare tendency among politicians and academics in Britain during the 1970s: they deliberated seriously on the Northern Ireland problem, placed it in a broad UK and British Isles context, and foreswore glib explanations if not, in Mackintosh's case for a short time, far-fetched solutions. Northern Ireland in a sense brought together a number of themes that preoccupied both men: devolution and the Stormont experience of it; the quasi-federalist character of the UK; constitutional reform; the impact of the Northern Ireland conflict on Britain; the relevance of questions of sovereignty and identity; and the way the sets of relationships that distinguished the British Isles had taken shape and might develop in the future.

Both Crick and Mackintosh tilted against the conventional anglo-centric version of Britain/ UK and its history and politics. They were aware that this concealed the extent to which different parts of the UK interacted and formed the whole, including Ireland and later Northern Ireland. Crick's generous welcome of Hugh Kearney's The British Isles published in 1989 reflected his belief that a decisive turn away from works of English history that masqueraded as 'British' history was underway; indeed, he has been proved correct. ${ }^{\text {xi }}$ Both Crick and Mackintosh were frustrated by what they saw as English indifference to constitutional matters and to questions of how the UK and the Union might be modernised and reformed, so that it could better defend itself against pressures towards break-up. In some telling interventions in the late 1980s, Crick tried to provoke his fellow English to engage with not only Northern Ireland, but also the growing consensus in Scotland around the need for a devolved parliament. ${ }^{\text {xcii }}$ He despaired, as Mackintosh had done during the devolution debates of the 1970s, of an unreflective English tendency to conflate Englishness and Britishness, to assume the unchallengeable orthodoxy of parliamentary sovereignty, to trust in some mystical way to the venerability of institutions. Crick, near the end of his life, welcomed what he viewed as a growing tendency among the English to think of themselves as such rather than 'super-British'xciii; the politics of the Union, he believed, ought to revolve around the necessary bargaining, sacrifices, trust and flexibility - the constant state of negotiation - that was inescapably part of such a multi-national and multi-cultural polity. ${ }^{\text {xciv }}$ Out of constructive and imaginative politics and the constant search for 'ways to reconcile diversity' ${ }^{\text {xcv }}$, he envisaged the emergence of a thicker and more expansive idea of citizenship and belonging. ${ }^{\text {xvi }}$

Northern Ireland in the 1970s was not an easy case study in pushing for the triumph of the form of politics advocated by both Mackintosh and Crick. Nevertheless, they recognised its relationship to the 'Union State' which they saw behind the constitutional mythology and the 'Unitary State' mirage. They felt that treating Northern Ireland as a 'place apart' only weakened the case for broad 'Union 
State' reform of the UK. Northern Ireland was part of the task of disaggregation and acknowledgement of diverse political cultures that had to take place to create the possibility of re-constructing a pluralist and progressive United Kingdom.

\footnotetext{
' See Ball, Defending Politics, 'Introduction'.

${ }^{i i}$ Crick recalled this in his contribution to a booklet, In Memory of John P. Mackintosh, 1929-1978, that he was instrumental in producing after Mackintosh's death. The booklet was published under the imprint of Political Quarterly in 1979.

iii Ibid. See also Walker, 'John P. Mackintosh'.

iv Ball, Defending Politics, xii.

v Mackintosh, Devolution of Power. The Scottish National Party's by-election victory at Hamilton in November 1967 was the most obvious sign of this upsurge. See Harvie, Scotland.

vi Mackintosh, 'The Problems of Devolution'.

vii Mackintosh, 'Devolution, regionalism and the reform of local government: the Scottish case', in Drucker, John P. Mackintosh.

viii Mackintosh, Devolution of Power.

ix Miles Taylor, 'Labour and the Constitution'.

x Mackintosh, 'Nationalist Eyes'. Mackintosh was consistently to refer to the 1920 Act as a benchmark to be followed, even as late as 1978 - see House of Commons Debates $5^{\text {th }}$ Series, Vol. 941, 11 January 1978, cc. 1697-8.

${ }^{x i}$ Submission in Drucker (ed.), John P. Mackintosh. Mackintosh highlighted the issue of Northern Ireland's parliamentary representation under devolution and its relevance for Scotland and Wales. ${ }^{x i i}$ Report of the Royal Commission on the Constitution (London, HMSO, 1973), Cmnd. 5460, more commonly known as the 'Kilbrandon Report' after the name of the Commission's Chairman from 1972. The Report concluded by recommending Stormont-style devolution for Scotland and Wales. xiii The Times, 30 March 1973.

xiv See correspondence in Chichester-Clark Papers, Churchill College Cambridge, CCLK/3/22.

${ }^{x v}$ Mackintosh Papers, National Library of Scotland (NLS), dep. 323/288. The period covered by this correspondence spanned 1968-75. It contains the letters from which the following quotes are drawn.

${ }^{\text {xvi }}$ Hand to Mackintosh 8 October 1968 and reply 18 October; Mackintosh to Hand 8 November 1968.

${ }^{x v i i}$ Hand to Mackintosh 16 August 1969. Hand was a scholarly authority on the subject of the Boundary Commission - see his introduction to Report of the Irish Boundary Commission, 1925 (Shannon: Irish University Press, 1969).

xviii Mackintosh to Hand 22 August 1969; and 4 September 1969.

xix The IRA split in December 1969 between those - the 'Provisionals' - who were militaristic rather than political in their approach, and the 'Officials' who were heavily influenced by Marxist ideology but who nonetheless were responsible for various acts of violence during the 1970s.

${ }^{x x}$ Mackintosh to Hand 10 February 1972. In relation to the suggestion of re-drawing the border, Mackintosh appears to have been well informed. See The Times, 1 January 2003, 'Heath drew up plan for partition in Northern Ireland'. Also, David McKittrick, 'Iron Lady did gaze on a new frontier', Belfast Telegraph, 6 January 2014.

xxi Hand to Mackintosh 10 September 1972.

xxii Mackintosh to Hand 15 March 1973. House of Commons Debates $5^{\text {th }}$ Series, Vol. 853, cc. 1041-2, 28 March 1973. Mackintosh also hoped that the White Paper would split the Ulster Unionist Party . It did indeed do this with UUP leader Brian Faulkner losing a vote in his party over Sunningdale and resigning, later forming his own Unionist Party of Northern Ireland (UPNI) - but not sufficiently for Mackintosh's political hopes to be realised.

xxiii Mackintosh to Hand, 26 December 1973.

xxiv Mackintosh to Hand, 7 March 1974. The coalition of Unionists (see footnote xxxiv) opposed to the Sunningdale Agreement won 11 out of the 12 Northern Ireland seats.

${ }^{x x v}$ Mackintosh to Hand 27 November 1974.

xxvi Mackintosh to Hand 31 December 1974.

xxvii Mackintosh 'Federalism'; see also Boyce, 'Dicey'.

xxviii The terms 'Union' and Unitary' State derive in academic discourse from Rokkan and Urwin in their introduction to the edited book The Politics of Territorial Identity. See also discussion in Mitchell, Devolution, and McLean and McMillan, State of the Union.

xxix Mackintosh, 'Devolution Fall Out'; Mackintosh, 'The Killing'.
} 
xxx See, for example, Conservative devolution spokesman Francis Pym's dismissal of Northern Ireland in 1978 as 'not part of the mainland': Churchill College Archives, Thatcher Papers, THCR 2/6/1/89.

The exception in this regard was Enoch Powell who wished to see Northern Ireland participate fully in what he called the 'British Nation'. See Cothorn, 'Enoch Powell'.

xxxi See Ball, Defending Politics.

xxxii See Crick, Essays on Citizenship. See also Jeffery, 'Citizen Crick'.

xxxiii Aughey and Gormley-Heenan, 'Freedom'.

xxxiv There is some autobiographical reflection in this respect contained in Crick's 1996 essay 'Why the Northern Ireland Peace Process must take so long', included in Crick, Crossing Borders.

${ }_{\mathrm{xxxv}}$ Memo sent by Crick in correspondence to William Rees-Mogg, editor of The Times, 10 October 1975, Bernard Crick Papers, Birkbeck College London, 3/4/4. The UUUC was a coalition of Unionist Parties and groupings opposed to the Sunningdale Agreement of 1973, and the power-sharing executive it gave rise to that sat from January 1974 until May 1974 and was dissolved following the Ulster Workers Council (UWC) strike of the latter month. For succinct accounts of these events, initiatives and organisations see Gillespie, Historical Dictionary. The most recent scholarly treatments of the failure of the attempts to end the conflict in the early 70s include Kerr, Destructors; and McDaid, Template.

xxxvi See Paddy Devlin's somewhat jaundiced view of the British government role in his autobiography Straight Left. Devlin was then a leading figure in the SDLP who had served in the short-lived powersharing executive in 1974.

xxxvii See the memoirs of the Secretary of State Merlyn Rees, Northern Ireland; also the memoir of senior Northern Irish civil servant Maurice Hayes, Minority Report; and Arthur, Special Relationships, p 161.

xxxviii Godson, Himself Alone, p.54

xxxix Trimble to Crick, 24 June 1975, Crick Papers, 3/4/4. See also Arthur, Special Relationships, pp. 111-112.

${ }^{\mathrm{xl}}$ Northern Ireland Constitutional Convention, Report of Debates, 30 September 1975, p. 555.

xli Crick memo, see footnote xxxiv.

xlii For British government appraisals of Craig at this juncture see The National Archives (TNA), CJ4/1436; FCO/ 87.

xliii PRONI, CONV/1/2, File on Convention; Kerr, Destructors (Dublin: Irish Academic Press, 2011), ch. 10; Jackson, Home Rule, ch. 11.

xliv See Commentary on 'Northern Ireland' originally published in Political Quarterly in 1976 and reproduced in Ball (Ed.), Defending Politics, p.511; also Crick, 'Why the Northern Ireland Peace Process'; and Aughey and Gormley-Heenan, 'Freedom'.

xlv Memo/ letter to Rees-Mogg - see note xxxvi.

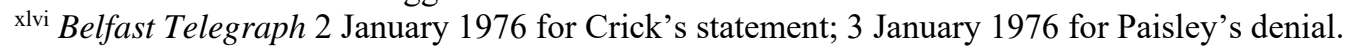

xlvii Letter dated 23/12/75.

xlviii Crick to Rose, 14 October 1975, Crick Papers, 3/4/4. Paddy Devlin later claimed that Paisley consulted with his church members who warned him against going along with it: see Devlin, Straight Left, pp. 262-3.

${ }^{x l i x}$ Crick Papers, 3/4/4: Memo written by BC enclosed in letter to Craig 3 October 1975 and sent to others such as Times editor William Rees-Mogg.

${ }^{1}$ PRONI, CONV/1/2, Meeting with the Chairman, 24 September 1975.

${ }^{\text {li }}$ Letter from Crick to Craig, 3 October 1975, Crick Papers 3/4/4.

lii See discussion in Walker, A History of the Ulster Unionist Party, pp. 224-5.

liii See Walker, 'Scotland'.

liv Belfast Telegraph, 2 January 1976.

lv PRONI, CENT/1/4/33, meetings 26 December 1975, and 30 December 1975.

${ }^{\text {lvi }}$ Crick Papers, 3/4/4, Crick paper on UUUC Sub-Committee Report on Minority Participation [emphasis in original]. This was the paper from which Trimble quoted in the Convention.

lvii See Walker, 'John P. Mackintosh'.

lviii See, for example, the Commentary 'Ten Years in Ulster' in Political Quarterly, January-March 1979, reproduced in Ball, Defending Politics, pp. 535-540.

lix 'Commentary', Political Quarterly, July-Sept. 1976, reproduced in Ball, Defending Politics, p. 511.

${ }^{1 x}$ Walker, 'Scotland'.

1xi TNA, FC87/554, memo dated 25 February 1976.

lxii TNA, CJ4/784, 'Call on the P.M.', 30 October 1975; and CJ4/1436, 'Note on Meeting between the Secretary of State and the Vanguard Unionist Party, 25 November 1975'. 
lxiii Craig had called on Unionists to resist any attempt by Westminster to take back devolved powers at the time of his sacking from the Northern Ireland government in December 1968. See the exchange of letters between Craig and Prime Minister Terence O'Neill in Robin Chichester-Clark Papers, Churchill College Archives Cambridge, 1/8. See also Miller, Queen's Rebels, pp. 123; 155-6.

lxiv Watson, 'Meticulously Crafted Ambiguities'.

${ }^{\mathrm{lxv}}$ Professor of Jurisprudence at Queen's University Belfast. See his edited book, Devolution of Government: The Experiment in Northern Ireland (1953). Newark also served on the Royal Commission on the Constitution (later popularly referred to as 'Kilbrandon Commission') between 1969 and 1973.

lxvi Chichester-Clark Papers, 3/22: Michael Lathan to (Prime Minster) Edward Heath, 6 August 1970.

lxvii TNA, CJ4/536, Ken Bloomfield memo on 'Devolution: the Northern Ireland Experience', dated 19

December 1974. See also discussion in Boyce, 'Dicey'.

lxviii ‘Commentary’ in Political Quarterly July-Sept. 1977.

lxix ‘Commentary’ in Political Quarterly, Jan.-March 1979.

${ }^{1 x x}$ Morison and Livingstone, Reshaping Public Power, pp. 105, 235. For examples of Crick's later writings on Northern Ireland that refer back to the 1973 Act $_{2}$-see his 1986 essay 'Northern Ireland and the Theory of Consent', in Crick, Political Thoughts and Polemics; and his essay 'The British State: Sovereignty and Identities', in English and Townshend (eds.), The State.

lxxi ‘Commentary', Political Quarterly, Jan - March 1979.

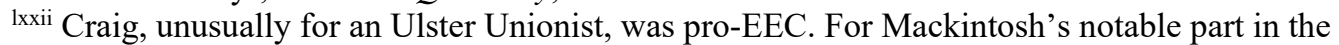
referendum campaign see Jenkins, Life in the Centre, p. 320.

lxxiii See 1988 essay 'On Devolution, Decentralism and the Constitution' in Crick, Political Thoughts and Polemics.

lxxiv House of Commons Debates, $5^{\text {th }}$ Series, Vol. 903, Columns 81-2, 12 January 1976.

lxxv Ibid., column 107.

lxxvi See Edwards (ed.), A Claim of Right.

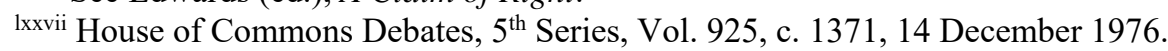

lxxviii Ibid., c. 1592.

lxxix TNA, CAB 128/58, 4 March 1976; FCO 87/ 554, 'Note for the Record' 27 February 1976, and Rees statement 5 March.

lxxx See TNA, CJ4/ 1440 for material charting the progress of these talks.

lxxxi Crick Papers, 2/2/3, letter dated 3 March 1976.

lxxxii See Walker and Mulvenna, 'Northern Ireland Representation'. See also Crick's criticisms of the Government over this issue in 'Ten Years in Ulster' in Political Quarterly, January-March 1979, reproduced in Ball, Defending Politics, pp. 535-540.

lxxxiii See Cooke, 'Enoch Powell and Ulster'.

lxxxiv The Scottish political commentator Neal Ascherson wrote of Craig in 1977 'clinging to his dream of fitting a Protestant Ulster with inviolable and entrenched rights into a federal Britain.' See extract from Ascherson's 'Devolution Diary' 23 February 1977 in Edinburgh Review No. 100 (1999), p. 114. lxxxv See the important collection of essays edited by Charles Townshend, Consensus in Ireland to which both Crick and Trimble contributed. For Crick's comments on the work of Boyle and Hadden see 'Northern Ireland and the Theory of Consent' in his collection Political Thoughts and Polemics.

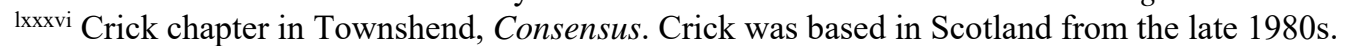
lxxxvii Examples of such work could be said to be Kearney, Postnationalist Ireland; Delanty 'Northern Ireland'.

lxxxviii See in particular the following essays by Crick: 'The Sovereignty of Parliament and the Irish Question'; 'An Englishman considers his passport'; and 'On Devolution, Decentralism and the Constitution', all in Crick, Political Thoughts and Polemics. The original publication dates of these pieces are 1982, 1988, and 1988 respectively.

lxxxix Crick, 'The English and the British', in Crick (ed.), National Identities ; also Crick, 'On Devolution'; and Crick, 'Why the Northern Ireland Peace Process must take so long'.

${ }^{x c}$ See Crick, 'The Four Nations', reproduced in Ball (ed.), Defending Politics, pp. 307-317.

${ }^{x c i}$ See review in Political Quarterly, 61, 4 (1991); also Crick, 'The Sense of Identity of the Indigenous British', in his Crossing Borders; and 'The English and the British' in Crick (ed.), National Identities for praise of Kearney and criticism by comparison of the historian Keith Robbins for failing to include Northern Ireland in his analysis of British identity. For a recent example of a more integrative approach to the subject see: Harrison, Finding a Role?

xcii 'An Englishman considers his passport', in Political Thoughts and Polemics; 'For my Fellow English', in Crossing Borders. 
xciii Crick, Review of Arthur Aughey's The Politics of Englishness, in Scottish Affairs No. 66 (2009), pp. 95-98.

${ }^{\text {xciv }}$ Crick was fond of comparing the Thatcherite tendency to govern the UK with no allowance made for its diversity with the more pragmatic and shrewd approach of an older governing class. See his review of Aughey in Scottish Affairs No. 66 (2009).

xcv See Jeffery, 'Citizen Crick'.

${ }^{\text {xcvi }}$ See Introduction to Crick (ed.), Citizens. 


\section{Bibliography}

Arthur, P. Special Relationships. Belfast: Blackstaff Press, 2000.

Aughey, A. and C. Gormley-Heenan, 'Freedom, Peace and Politics: Crick and Northern Ireland', Political Quarterly 83, no. 4 (2012): 653-659.

Ball, S. (ed.), Defending Politics. Bernard Crick at The Political Quarterly. West Sussex: WileyBlackwell, 2015.

Boyle K. and T. Hadden. Ireland: A Positive Proposal. Harmondsworth: Penguin Books, 1985.

Boyce, D.G. ‘Dicey, Kilbrandon and Devolution', Political Quarterly 46 (1975): 280-292.

Cooke, A. 'Enoch Powell and Ulster'. In Enoch at 100. Edited by Lord Howard of Rising, London: Biteback Publishing, 2014.

Cothorn, P. 'Enoch Powell, Ulster Unionism, and the British Nation', Journal of British Studies 51, no.4 (2012): 967-997.

Crick, B. The Reform of Parliament. London: Weidenfeld and Nicholson, 1964.

Crick, B. Political Thoughts and Polemics. Edinburgh: Edinburgh University Press, 1990.

Crick, B., ed. National Identities. Oxford: Blackwell, 1991.

Crick, B. Essays on Citizenship. London: Continuum, 2000.

Crick, B. Crossing Borders. London: Continuum, 2001.

Crick, B., ed. Citizens. Towards a Citizenship Culture. Oxford: Blackwell, 2001.

Crick, B. ‘The Four Nations: Interrelations', Political Quarterly 79, no. 1 (2008).

Delanty, G. 'Northern Ireland in a Europe of the Regions', Political Quarterly 67, no. 2 (1996): 127134.

Devlin, P. Straight Left. Belfast: Blackstaff Press, 1993.

Drucker, H., ed. John P. Mackintosh on Scotland. London: Longman, 1982.

Edwards, O.D., ed. A Claim of Right For Scotland. Edinburgh: Polygon, 1989.

English, R. and C. Townshend, eds. The State: Historical and Political Dimensions. London: Routledge, 1999.

Gillespie, G. Historical Dictionary of the Northern Ireland Conflict. Plymouth: Scarecrow Press, 2008.

Godson, D. Himself Alone. London: HarperCollins, 2004.

Harrison, B. Finding a Role? The United Kingdom 1970-1990. Oxford: Oxford University Press, 2010.

Harvie, C. Scotland and Nationalism. London: Routledge, 1998. 
Hayes, M. Minority Report. Belfast: Blackstaff, 1995.

Jackson, A. Home Rule: An Irish History. London: Weidenfeld and Nicholson, 2003.

Jeffery, C. 'Citizen Crick: Politics as Theory and Practice', Scottish Affairs No. 67 (2009): 1-6.

Jenkins, R. Life in the Centre. London: Politicos, 2006.

Kearney, R. Postnationalist Ireland. London: Routledge, 1997.

Kerr, M. The Destructors. Irish Academic Press, 2011.

McDaid, S. Template for Peace. Manchester: Manchester University Press, 2013.

Mackintosh, J.P. The Devolution of Power. London: Penguin Special, 1968.

Mackintosh, J.P. 'Nationalist Eyes on Ulster’s System’, The Times 6 August 1968.

Mackintosh, J.P. 'Federalism: Central/Regional Government Relations'. Seminar paper No. 1, 1974-5, Paper 3, University of Edinburgh Centre of Canadian Studies.

Mackintosh, J.P. 'The Problems of Devolution - the Scottish Case'. In From Policy to Administration, edited by J.A.G. Griffiths, London: Allen and Unwin, 1976.

Mackintosh, J.P. 'Devolution Fall Out', The Scotsman 29 March 1976

Mackintosh, J.P. 'The Killing of the Scotland Bill', Political Quarterly 49 (1978): 127-132.

Mclean, I. and A. McMillan, State of the Union. Oxford: Oxford University Press, 2005.

Miller, D.W. Queen’s Rebels. Dublin: UCD Press, 2007.

Mitchell, J. Devolution in the UK. Manchester: Manchester University Press, 2009.

Morison, J. and S. Livingstone, Reshaping Public Power: Northern Ireland and British Constitutional Crisis. London: Sweet and Maxwell, 1995.

Rees, M. Northern Ireland: A Personal Perspective. London: Methuen, 1985.

Rokkan, S. and D. Urwin, eds. The Politics of Territorial Identity. London: Longman, 1982.

Taylor, M. 'Labour and the Constitution'. In Labour's Century. edited by D. Tanner et al, Cambridge: Cambridge University Press, 2000.

Townshend, C., ed. Consensus in Ireland. Oxford: Clarendon Press, 1988.

Walker, G. A History of the Ulster Unionist Party. Manchester: Manchester University Press, 2004.

Walker, G. 'Scotland, Northern Ireland and Devolution, 1945-79', Journal of British Studies 49, no.1 (2010): 117-142.

Walker, G. 'John P. Mackintosh, Devolution and the Union', Parliamentary Affairs 66, no. 3 (2013): 557-578

Walker, G. and G. Mulvenna. 'Northern Ireland Representation at Westminster: Constitutional Conundrums and Political Manoeuvres', Parliamentary History 34, Part 2 (2015): 237-255. 
Watson, G. 'Meticulously Crafted Ambiguities: The Confused Political Vision of Ulster Vanguard', Irish Political Studies 28, no. 4 (2013): 536-562. 